\title{
PKM Kelompok Lanjut Usia dalam Penatalaksanaan Rematik di Panti Sosial Tresna Werdha Budi Luhur
}

\author{
Tina Yuli Fatmawati ${ }^{1}$, Ariyanto ${ }^{2}$ \\ ${ }^{1,2}$ Program Studi Diploma III Keperawatan, STIKes Baiturrahim Jambi \\ email: tinayulifatmawati@gmail.com
}

Submitted : 15/01/2020

Accepted: 19/01/2020

Published: $31 / 01 / 2020$

\begin{abstract}
Health problems that often occur in the elderly is rheumatism. Rheumatism is a disease that attacks the joints and bones or supporting tissues around the joints, this disease group is an autoimmune disease that is mostly suffered by the elderly. Initial survey conducted at Panti Sosial Tresna Werdha Province found that most of the elderly suffer from rheumatism. current partners, among others, the Information and Education Communication Media, such as rheumatism gymnastics posters, are still lacking. Some elderly people do not understand the traditional methods of treatment for rheumatic pain prevention. Targets and outcomes: In addition to the outputs in journals, the targets in this community service are Carrying out health counseling activities for the elderly about managing rheumatism with traditional ingredients (Ginger therapy) by $80 \%$. Rheumatic sufferers understand how to make ginger therapy ingredients, making media (posters) and rheumatism exercises. Implementation methods include education about rheumatism, rheumatism exercises, educational media. The results obtained by the elderly understand about rheumatism, prevention and traditional treatment with grated jage, and man to carry out routine anti-diphythmic dip. It is hoped that the orphanage staff will be able to monitor, motivate and improve the health of the elderly through health promotion activities, especially regarding rematies.
\end{abstract}

Keywords: elderly, ginger therapy, rheumatic, rheumatic exercises

\begin{abstract}
Abstrak
Masalah kesehatan yang sering terjadi pada lanjut usia adalah rematik. Rematik merupakan penyakit yang menyerang sendi dan tulang atau jaringan penunjang sekitar sendi, golongan penyakit ini merupakan penyakit Autoimun yang banyak di derita oleh kaum lanjut usia Survey awal yang dilakukan di Panti Sosial Tresna Werdha Budi Luhur Provinsi Jambi ditemukan sebagian besar lansia menderita Rematik Permasalahan yang dihadapi mitra saat ini antaralain Media Komunikasi Informasi dan Edukasi (KIE) seperti poster senam rematik masih kurang, Sebagian Lansia belum memahami cara pengobatan tradisional tentang pencegahan nyeri rematik. Target dan luaran: Selain luaran pada jurnal, target dalam pengabdian masyarakat ini adalah Melaksanakan kegiatan Penyuluhan kesehatan pada lansia tentang penatalaksanaan rematik dengan ramuan tradisional (terapi Jahe) sebesar $80 \%$ Penderita Rematik memahami cara membuat ramuan terapi jahe, Pembuatan media KIE (poster) dan latihan senam rematik. Metode pelaksanaan meliputi edukasi tentang rematik, senam rematik, , pemberian media edukasi. Hasil yang diperoleh lansia memahami tentang rematik, pencegahan dan pengobatan tradisional dengan parutan jage, dan man melaksanakan senamrematik secara rutin dip anti. Diharapkan kepada petugas panti agar dapat memantau, memotivasi serta meningkatkan kesehatan lansia melalui kegiatan promosi kesehatan khususnya tentang remati.
\end{abstract}

Kata Kunci: lanjut usia, rematik, senam rematik, terapi jahe, 


\section{PENDAHULUAN}

Lanjut usia (Lansia) adalah kelompok manusia yang berusia 60 tahun keatas, pada lanjut usia akan terjadi proses menghilangnya kemampuan jaringan untuk memperbaiki diri atau menganti dan mempertahanan fungsi normalnya secara perlahan-lahan sehingga tidak dapat bertahan terhadap infeksi dan memperbaiki kerusakan yang terjadi (Sunaryo,2016) Lansia adalah suatu proses menghilangnya secara perlahan-lahan kemampuan jaringan untuk memperbaiki diri atau menganti diet dan mempertahankan struktur dan fungsi normalnya sehingga tidak dapat bertahan terhadap jejas dan memperbaiki kerusakan yang diderita (Darmojo, 2015). Kualitas hidup lansia terutama status fungsionalnya perlu ditingkatkan sehingga lansia dapat melakukan aktifitas sehari-hari secara mandiri. Masalah-masalah yang sering terjadi pada lanjut usia adalah rematik.

Rematik merupkan penyakit yang menyerang sendi dan tulang atau jaringan penunjang sekitar sendi, golongan penyakit ini merupakan penyakit Autoimun yang banyak di derita oleh kaum lanjut usia (usia 50 tahun ke atas). Penyakit ini lebih sering terjadi pada perempuan dan biasanya menyerang orang yang berusia lebih dari 40 tahun (Arif Muttaqin, 2008). Rematik terutama menyerang Sendi-sendi, tulang, ligamentum, tendon dan persendian pada laki-laki maupun perempuan dengan segala usia. Salah satu penatalaksanaan rematik secara tradisional adalah Kompres hangat jahe. Kompres jahe merupakan pengobatan tradisional atau terapi alternatif untuk mengurangi nyeri arthritis rhematoid (Dalimarta, 2008). Artrhitis rheumatoid (RA) adalah penyakit autoimun sistemik kronik yang menyebabkan inflamasi jaringan ikat, terutama di sendi. Penyebab RA tidak diketahui. Awitan RA biasanya tiba-tiba, meskipun mungkin akut, dipicu oleh stressor seperti infeksi, pembedahan, trauma. Faktor genetik dan lingkungan diyakini berperan dalam perkembangan penyakit ini (LeMone, 2017).

Panti Sosial Tresna werdha terletak di J1. Pangeran Hidayat No.75, Paal Lima, Kota Baru, Kota Jambi, memiliki kapasitas penghuni sebanyak 70 orang yang berasal dari daerah yang ada di propoinsi Jambi, bahkan ada yang dari luar Propinsi. Salah satu kegiatan yang dilakukan oleh panti werdha antara lain :1) Preventif yaitu: Melaksanakan kegiatan olahraga,seperti : membersihkan lingkungan, jalan pagi, dan senam lansia sekali seminggu, bersama puskesmas memeriksa kesehatan para lansia setiap hari kamis, Mengatur dan membiasakan para lansia untuk dapat tidur beristirahat secukupnya, 2) Kuratif, seperti : pengobatan untuk para lansia yang mengalami sakit-sakit ringan,dapat diberikan pengobatan langsung dengan obat-obat ringan yang disediakan panti. Bagi lansia yang mengalami sakit dan memerlukan perawatan / rawat inap,akan dirujuk ke RSU provinsi setelah mendapat rekomendasi dari dokter / Puskesmas. 3) Bimbingan mental dan spiritual : Untuk membiasakan lansia-lansia di UPTD PSTW melaksanakan ibadah sesuai dengan agama yang dianut,maka dilaksanakanlah kegiatan bimbingan mental spiritual, berupa ceramah-ceramah agama / pengajianpengajian bagi lansia

Survey awal yang dilakukan di Panti Sosial Tresna Werdha Budi Luhur Provinsi Jambi ditemukan sebagian besar lansia menderita Rematik, Lansia mengatakan sering kambuh rasa nyeri pada sebagian sendi kaki dan tangan terutama malam dan pagi hari, sebagian lansia tidak memahami cara tradisional mengurangi nyeri sendib tehnik senam rematik dengan benar.

Permasalahan yang dihadapi mitra saat ini antara lain Media Komunikasi Informasi dan Edukasi (KIE) seperti poster senam rematik masih kurang, Sebagian Lansia belum memahami cara pengobatan tradisional tentang pencegahan nyeri rematik. 


\section{TARGET DAN LUARAN}

Selain luaran pada jurnal, target dalam pengabdian masyarakat ini adalah $80 \%$ lansia mengetahui tentang penatalaksanaan rematik dengan ramuan tradisional (terapi Jahe) sebesar $80 \%$ Penderita Rematik memahami cara membuat ramuan terapi jahe , Pemberian media KIE (poster) dan latihan senam rematik.

\section{METODE PELAKSANAAN}

Pelaksanaan kegiatan pengabdian ini telah dilaksanakan pada bulan November-Desember 2018 dengan sasaran Lansia penderita rematik yang tinggal di Panti Werdha Budi Luhur Jambi. Tujuan dari pengabdian masyarakat ini diharapkan setelah mengikuti sosialisasi (penyuluhan dan demonstrasi) terapi jahe dan senam rematik, lansia mampu memahami dan mendemonstrasikan kembali tentang pemberian terapi kompres jahe dan senam rematik.

Adapun Metode pelaksanaan pengabdian kepada masyarakat di Panti Werdha telah dilakukan sesuai dengan rencana sebelumnya dan dapat diuraikan pada tabel 1 berikut ini:

Tabel 1. Metode Pelaksanaan kegiatan pengabdian kepada masyarakat

\begin{tabular}{|c|c|c|c|}
\hline No & Tahapan & Kegiatan & Metode 5 \\
\hline $\mathbf{A}$ & Persiapan & & \\
\hline 1. & Sosialisasi & & \\
\hline & $\begin{array}{l}\text { Pertemuan dengan } \\
\text { petugas Panti }\end{array}$ & $\begin{array}{l}\text { Penyamaan } \\
\text { persepsi }\end{array}$ & $\begin{array}{l}\text { Diskusi, C } \\
\text { tanya }\end{array}$ \\
\hline 2 & $\begin{array}{l}\text { Menyiapkan } \\
\text { bahan dan alat }\end{array}$ & & \\
\hline
\end{tabular}

\begin{tabular}{|c|c|}
\hline & Perumusan solusi \\
\hline & $\begin{array}{l}\text { Mengidentifikan } \\
\text { dan membahas } \\
\text { temuan yang ada }\end{array}$ \\
\hline & $\begin{array}{l}\text { Menyampaikan } \\
\text { solusi }\end{array}$ \\
\hline
\end{tabular}

Identifikasi
masalah
melalui
survey di
Panti
Solusi
mengenai
permasalah
an dan
strategi
pelaksanaa
nnya

\section{B Pelaksanaan}

1 Penyuluhan kesehatan

Penatalaksa

naan rematik dengan ramuan tradisional ( terapi kompres jahe)

2 Pemberian media KIE

Menempel

poster senam lansia Latihan senam Mempersia pkan Bahan dan alat

Pengukuran skala nyeri sebelum dan sesudah terapi

$\begin{array}{ll}\text { Kuesioner } & \begin{array}{l}\text { Tanya } \\ \text { jawab }\end{array} \\ & \\ & \begin{array}{l}\text { Diskusi,t } \\ \text { anya } \\ \text { jawab }\end{array}\end{array}$

Diskusi, tanya jawab (a) 


\section{HASIL DAN PEMBAHASAN}

Kegiatan pengabdian masyarakat di Panti Werdha telah dilaksanakan sesuai dengan rencana yang telah disusun. Kegiatan Penyuluhan dilaksanakan kepada warga khususnya lansia yang menderita rematik di Panti Sosial Tresna Werdha. Kegiatan ini dibantu oleh mahasiswa/i program studi D3 Keperawatan. Kegiatan penyuluhan ini bertujuan agar warga panti memahami tentang bagaimana cara membuat ramuan tradisional dengan terapi kompres jahe yang sebelumnya dilakukan pengukuran skala nyeri (pretest) dan sesudah terapi dilakukan test pengukuran skala nyeri (posttest).

Kegiatan dimulai dengan penyuluhan kesehatan tentang rematik yang dihadiri oleh 10 orang lansia yang menderita rematik. Lansia sangat antusias dalam mengikuti kegiatan. Beberapa lansia bertanya perihal upaya pencegahan kekambuhan rematik. Kemudian dilanjutkan dengan demonstrasi pemberian kompres jahe. Pada hari berikutnya tim memberikan media edukasi berupa poster dan booklet tentang tehnik senam rematik.

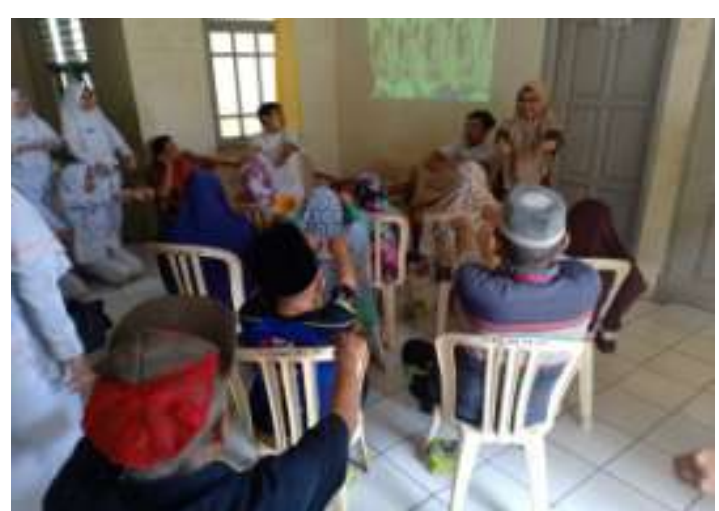

Gambar 1. Pendidikan kesehatan dan senam rematik

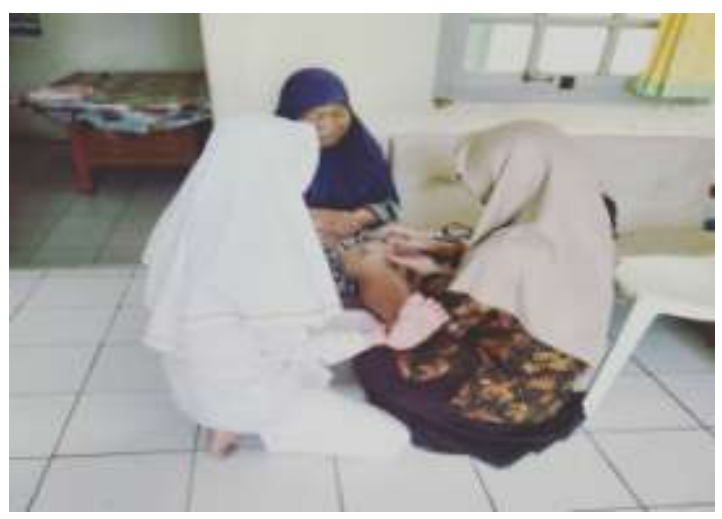

Gambar 2. Demonstrasi Kompres jahe
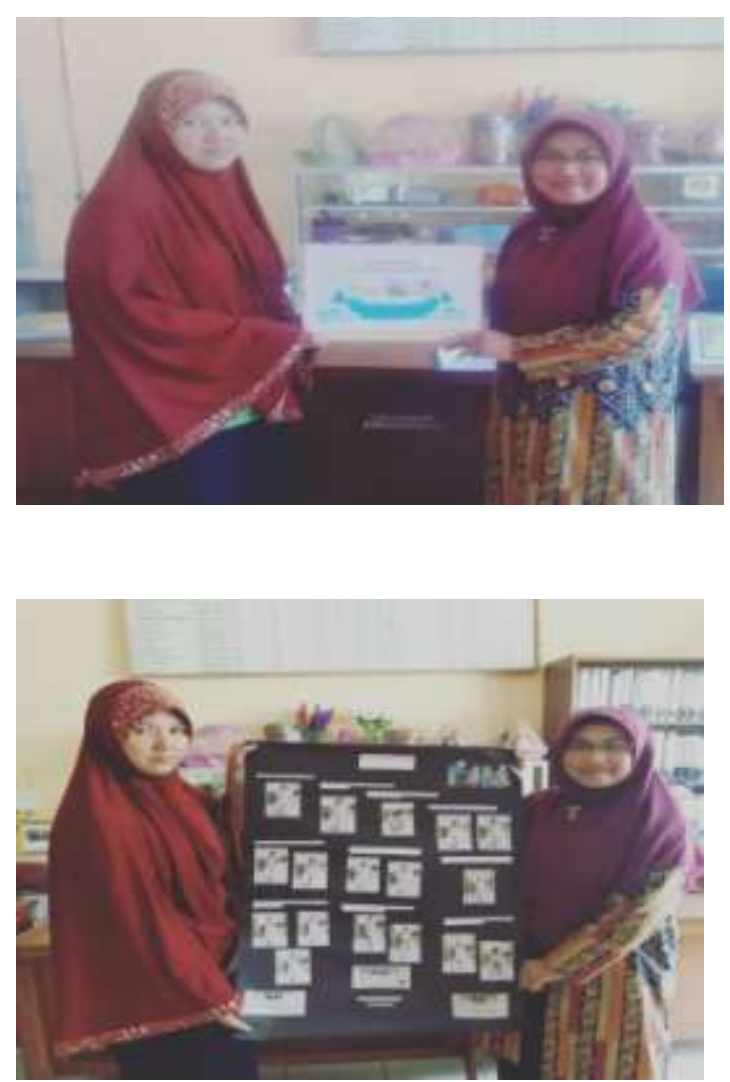

Gambar 3,4. Pemberian media edukasi

Kompres jahe merupakan pengobatan tradisional atau terapi alternatif untuk mengurangi nyeri arthritis rhematoid. Jahe memiliki kandungan enzim siklo oksigenasi yang dapat mengurangi peradangan pada penderita arthritis rhematoid selain itu jahe juga memiliki efek farmakologis yaitu rasa panas dan pedas, dimana rasa panas ini dapat meredakan rasa 
nyeri, kaku, dan spasme otot atau terjadinya vasodilatasi pembuluh darah, manfaat yang maksimal akan dicapai dalam waktu 15 menit sesudah aflikasi panas (Dalimarta, 2008). Berikut ini hasil pengukuran skala nyeri sebelum dan setelah dilakukan terapi kompres jahe:

Tabel. 2 Hasil pengukuran skala nyeri sebelum dan setelah dilakukan terapi kompres jahe

\begin{tabular}{cccc}
\hline $\begin{array}{c}\text { No } \\
\text { responden }\end{array}$ & $\begin{array}{c}\text { Umur } \\
\text { (th) }\end{array}$ & $\begin{array}{c}\text { Skala } \\
\text { nyeri pre }\end{array}$ & $\begin{array}{c}\text { Skala } \\
\text { nyeri post }\end{array}$ \\
\hline 1 & 76 & 6 & 4 \\
2 & 73 & 7 & 5 \\
3 & 65 & 6 & 4 \\
4 & 73 & 6 & 4 \\
5 & 70 & 8 & 6 \\
6 & 65 & 5 & 4 \\
7 & 65 & 6 & 3 \\
8 & 66 & 6 & 4 \\
9 & 60 & 7 & 5 \\
10 & 69 & 7 & 6 \\
\hline
\end{tabular}

Tabel diatas diperoleh hasil bahwa terdapat perubahan skala nyeri dari sedang menjadi ringan. Lansia merasa senang dengan adanya pemberian kompres jahe. Lansia mengatakan setelah diberikan kompres jahe dalam waktu 15-20 menit sendi terasa hangat dan nyeri berkurang.

kegiatan ini sejalan dengan penelitian sebelum hasil diperoleh pengaruh pemberian kompres jahe terhadappenurunan skala nyeri arthritis rheumatoid pada lanjut usiadi Panti Sosial Tresna Werdha Kota Jambi, (Fatmawati,TY, 2019)

\section{KESIMPULAN DAN SARAN}

\section{Kesimpulan}

Peserta Penyuluhan dapat memahami bagaimana cara membuat ramuan tradisional (terapi kompres jahe). Peserta penyuluhan mampu melaksanakan senam rematik secara mandiri.

\section{Saran}

Diharapkan kepada petugas panti agar dapat memantau, memotivasi serta meningkatkan kesehatan lansia melalui kegiatan promosi kesehatan terutama tentang bagaimana menjaga pola hidup sehat sehingga dapat mencegah kekambuhan pada rematik.

\section{UCAPAN TERIMAKASIH}

Terimakasih kepada kepala Panti Sosial Tresna Werdha, Petugas Panti dan Peserta Lansia yang hadir pada kegiatan pengabdian masyarakat serta STIKes Baiturrahim yang memberikan dukungan moril dan materil sehingga terlaksananya kegiatan pengabdian kepada masyarakat ini.

\section{DAFTAR PUSTAKA}

Depkes RI, 2010, Pedoman Umum Pengembangan Desa dan Kelurahan Siaga Aktif. Jakarta : Pusat Promosi Kesehatan Sekretaris Jenderal Kementerian Kesehatan RI

Darmojo,B.R, dan Martono.H. 2010. Buku Ajar Geriatri. Balai Penerbit FKUI. Jakarta.

Dalimartha, S. 2008. Herbal Untuk Pengobatan Reumatik. Penebar Swadaya. Jakarta.

LeMone, Priscilla, 2017. Buku Ajar Keperawatan Medikal Bedah; gangguan musculoskeletal. Jakarta: EGC, 2016

Padila. 2013. Buku Ajar Keperawatan Gerontik. Nuha Medika. Yogyakarta

Fatmawati TY, Ariyanto A, 2019, Pengaruh Kompres Jahe Terhadap Penurunan Skala Nyeri Arthritis Rheumatoid Pada Lanjut Usia Di Panti Sosial Tresna Werdha Budi LuhurJambi, https://www.researchgate.net/profile/ Arnati_Wulansari/publication/334694 453_PROSIDING_SEMINAR_NASI ONAL_GIZI_Penerbit_STIKes_Baitu rrahim_Jambi/links/5d3a550c299bf19 95b4af2d4/PROSIDING-SEMINARNASIONAL-GIZI-Penerbit-STIKesBaiturrahim-Jambi.pdf\#page $=119$ 